\title{
Research on English Teaching Mode of Multiple Interactions Based on
}

\author{
WeChat \\ Huahong Rao ${ }^{1}$ \\ ${ }^{1}$ Tongren University, Tongren, Guizhou, 554300 \\ 346591653@163.com
}

\section{KEYWORDS: English Teaching Mode; Multiple Interactions; WeChat}

\begin{abstract}
Teaching mode can play multiplier role in teaching effectiveness. The popularity of mobile Internet, as well as the widespread use of mobile social interaction application platform, such as WeChat, can provide conditions for the innovation of the teaching mode and implementation. In teaching practice, through the WeChat platform, the modern college English teaching activities composed of the teachers, students, teaching content and the network resources and so on, can be used to form six aspects of multivariate interaction, for instance, "teachers and the teaching content", "students and the teaching content", etc. , thus improving teaching effectiveness and students ability to use English.
\end{abstract}

\section{Introduction}

English teaching has always been an important part of our education, reform and opening up new requirements for national English language skills to enhance the quality of the new era of information technology and the rapid development of new challenges to traditional teaching methods and means of change, so that college English teaching has been facing emerging the new demands. The Ministry of Education in 2007 promulgated the "College English Curriculum Requirements" that "college English teaching goal is to train students in English language proficiency, especially listening and speaking," clearly want to "enhance the learning ability of students, enhance cultural awareness ", and the use of information technology to carry out new teaching model reform organization made a clear request Colleges and universities should take full advantage of modern information technology, computer-based and classroom English teaching model, improving teacher taught mainly single teaching mode. The new model should be based on modern information technology, especially network technology to support teaching and learning English cannot make the time and place restrictions to some extent, toward personalization and self-learning direction.

\section{Theoretical Basis for Multiple Interactive Teaching Mode}

Theoretical Basis for Multi interactive teaching model is constructivist learning theory and blended learning theory. Constructivist learning theory, in essence, is a branch of cognitive learning theory, the theory is by the Swiss philosopher and psychologist Jean Piaget (J. Piaget) create raised. The core idea is not to emphasize the knowledge acquired by the teacher to teach, but learners in a given scenario, you can use the relevant people (teachers or students, etc.) of power and assistance, with the necessary learning materials and specific tools, re-construction of the content and meaning 
of the way to get. Constructivism supported under the guidance of teachers, student-centered learning, emphasizing the role of students cognitive subject, while not ignoring the guidance of teachers, teachers are teaching the true meaning of its content to help reconstruct, facilitator rather than simply impart knowledge and inculcate those. Students are taught classroom teaching content reworked subjects, information and meaning to reconstruct who, rather than simply relying on external stimulus passive acceptance.

\section{The Material Basis for the Implementation of Multiple Interactive Teaching Mode}

With the popularity of the Internet, multimedia and network technology in modern English teaching it has been widely used. Especially the rapid development in recent years mobile network terminals, the number of mobile Internet users rapid, easy to accept new things most college students, mobile Internet coverage is almost $100 \%$. Based mobile terminals developed using a variety of application software (APP), showing a strong advantage and function, but also for English teaching university students under the condition of information provided opportunities. Micro letter as the current largest mobile social media, with its innovative features and strong interaction by college students of all ages, which have a circle of friends, micro-channel group, voice and video communication, micro-channel public account platform and other functions, but also for college students to learn provide more convenient, fast, rich content channels. First, flexible, students can choose their own time and place always open micro-channel network logon account to learn. Second, rich content, students can enjoy a rich, vivid and interesting course materials, and according to their own preferences to select an image, sound, animation, video and text and other knowledge carriers. Third, real-time interaction, in the new teaching model, between teachers and students, synchronous or asynchronous interaction between life and life becomes more convenient and efficient. Fourth, self-expression, the rapid development of information technology, making social interaction into the self-media age, everyone is media, relying on the use of micro-channel platforms, the original lack of voice.

\section{The Principles of Multiple Interactive Teaching Mode Should be Followed}

\section{A. Guiding and promoting principles of teachers and inspectors}

Under the new teaching model, not just a teacher who taught, and turned to a multi-role: curriculum designers, organizers and monitor the activities of those teaching, imparting knowledge screeners, skills training director, director of student learning and facilitator. The main task of teachers is to guide students adjust to college English teaching, learn to use new techniques, use of network resources query knowledge of English, knowledge of English organizational integration points, to build their own knowledge structure system, complete internalization of knowledge.

\section{B. The principle of student's self-study}

Dominant position of students is the core of the teaching process. Therefore, we should give full play to the students' training and self-learning ability. Under the new teaching model, teachers should give students self-sufficient space to encourage students to be self-use of network resources can be carried out in accordance with the student teachers of Internet resources online learning, and self-regulated learning progress, but also through information dissemination and mutual interest of group members to facilitate the successful completion of the teacher layout learning tasks. 


\section{Teaching content-based principle.}

The ever-changing information technology tools, colorful network resources, not to say that college English teaching it is entirely possible to subvert the traditional model of the past, the main front of the classroom teaching role to play in the final analysis, or rely on high-quality teaching content. When the technology or information transfer means dominant, people often have a misunderstanding, it is the ways and means and the main transmission channels. As everyone knows, without strong support for premium content alone it is difficult to form a variety of ways to achieve the desired effect of teaching.

\section{Content and Implementation of Multiple Interactive Teaching Model}

\section{A. Interaction between teachers and teaching content.}

Before teaching, teachers should students' knowledge level and ability to analyze the content of teaching and the teaching content related to the integration of knowledge, and passed to the students through the network platform. Start with "what to teach" start thinking "how to teach", simulation exercises in classroom teaching mode, design students loved teaching activities to develop students' potential, mobilize students enthusiasm and initiative; then from the "teach how to" start teaching summary experience, improve teaching effectiveness.

\section{B. Interactive between student and teaching content.}

In order to fully play the main role of students and to develop their innovative thinking consciousness, and teaching students to timely interactive content. Before class, students should be effective preparation, advance understanding of classroom content, active thinking, identify problems and seek to solve the problem. In class, students under the guidance of teachers to address unresolved issues in rehearsal, and actively participated in a series of teachers teaching activities designed to further enhance problem solving and integrated use of language knowledge.

C. The interaction between students and teachers.

Teachers and students are four elements in the "live" element, so the teacher-student interaction is the most direct expression of classroom teaching. Under the new teaching model, teachers and students in the classroom can be achieved not only face to face interaction, but also to achieve lower class use micro-channel platform online in real time interaction.

D. The interaction between students and student.

College English Teaching outstanding student-centered, not only to highlight the dominant position of the individual students, but also concerned about the dominant position of the guide and focus on mutual recognition between students and students, through the organization to mobilize interaction among students, to efficiently promote the student body play a role. Thus, learning activities can take advantage of micro-channel group or circle of friends, by focusing on the point Like and comment together to complete the process of inquiry learning task.

\section{E. Interaction between teachers and network platforms.}

English network resource vast as the sea, the student will be faced with the problem of no choice, therefore, teachers should fully integrate network resources, download content as a guide student learning; provide English language learning website and web queries to gather information for students and online learning. At the same time, teachers should actively communicate online with students to understand and address the learning process problems. 


\section{Conclusions}

Under Multiple interactive teaching mode, we need to pay attention to the teachers to teach, but also pay attention to students' learning, both should combine together; by promoting science teachers Guidance inspectors, change the past, a single student in the classroom imparting knowledge to receiving mode, you can create a pleasant learning environment for students and diverse, maximize their students' participation consciousness and self-display of self-confidence, improve the students take the initiative to acquire knowledge of enthusiasm and initiative.

\section{REFERENCE:}

[1] PIAGET J. The Origins of Intelligence in Children [M]. New York: International Universities Press, 1966: 163 $-164$.

[2] Ho Lai. Multiple transition Interactive College English Teaching teachers and students in the role of the role of [J]. Changchun University of Technology, 2009 (3): 481-483.

[3] Liming Dong. Independent College English Autonomous Learning Mode relatively non-autonomous teaching and to Cheng Yi College of Jimei University [J]. Huaihai Institute of Technology, 2012 (13): 103-105.

[4] Yang Runfen. Cooperative Learning in College English Teaching [J]. Language and Cultural Studies, 2013 (11): 99-101.

[5] Shi Yan. And Reflection on College English Teaching Practice Blackboard platform [J]. Education Forum, 2013 (27): 201-202. 